\title{
The Impacts of Customer Interaction and Social Capital on New Service Development Performance
}

\author{
Zhaoquan Jian, Yan Liu \\ School of Business Administration, South China University of Technology, Guangzhou, China \\ Email: 18814098091@139.com
}

How to cite this paper: Jian, Z.Q. and Liu, Y. (2016) The Impacts of Customer Interaction and Social Capital on New Service Development Performance. American Journal of Industrial and Business Management, 6, 1133-1145.

http://dx.doi.org/10.4236/ajibm.2016.612106

Received: November 24, 2016

Accepted: December 20, 2016

Published: December 23, 2016

Copyright $\odot 2016$ by authors and Scientific Research Publishing Inc. This work is licensed under the Creative Commons Attribution International

License (CC BY 4.0).

http://creativecommons.org/licenses/by/4.0/

\begin{abstract}
Customer interaction has a positive impact on new service development of firms. Nowadays, in the networked economies and societies, the importance of social capital as related to new service development performance is also becoming prominent. However, the existing literature does not reveal much about the relationships among the three variables. Based on customer cooperation innovation theory and new service development theory, this paper tested hypotheses by using the empirical data of 219 knowledge intensive business service firms in the Pearl River Delta of China. The study finds that customer interaction has a distinct positive impact on new service development performance; and social capital has a distinct positive impact on new service development performance. Furthermore, social capital plays a regulatory role in the relationship between customer interaction and new service development performance. By exploring the issues above, the paper will enrich research in the area of service science, especially new service development in China. Meanwhile, our findings will help managers to improve new service development performance by utilizing customer interaction and social capital.
\end{abstract}

\section{Keywords}

Customer Interaction, Social Capital, New Service Development Performance

\section{Introduction}

Since the concept of open innovation is proposed, more and more attention has been paid to customer cooperation innovation in the field of innovation research [1]. Customer interaction refers to the process of dynamic activity in which enterprise and customer collaborate and innovate around specific projects under guidance of value cocreation orientation. Nowadays, the impact of customer interaction on new service development performance has become focus of research in the field of customer coopera- 
tion innovation. Most of the existing literatures try to reveal the impact of customer interaction on new service development performance by analyzing its mediation effect [2] [3]. Social capital is the sum of resources on the basis of network relationship. However, how the impact from external key resources reflects to facilitation of customer interaction on new service development performance is still very limited. Therefore, to explore the regulatory role of social capital in the relationship between customer interaction and new service development performance is to further promote and deepen the research on customer cooperation innovation and new service development performance.

Most of the existing research explores technology innovation or product innovation [4] [5] [6] [7] [8], while the innovation of the new service development process is not sufficiently focused. New service development refers to the innovation of service concept, service submission interface, service submission system, service support technology under joint promotion of internal organizational and external environmental factors, so as to provide new or improved service to customers. However, because service itself is different from product, the success of product innovation does not necessarily apply to service innovation [9]. New service development project has the feature of "private customization" [10], whether traditional product management theory is still applicable, further studies are needed. How to fully absorb the policy, information or funds support the external social capital brings [11], then improve new service development performance and achieve the high ground of future competition, is also an urgent question to be answered.

Further analysis shows that the relationship among customer interaction, social capital and new service development performance has not yet been fully explored. Therefore, whether and how social capital plays a role in the relationship between customer interaction and new service development performance is an important issue, which needs to be studied and discussed in this paper.

This paper is organized as follows. The theoretical basis and research hypothesis section reviews related literatures and points out assumptions. The following section describes sample selection and data collection, as well as the credibility and validity of data. Then, the overall model is presented to verify intrinsic relationships between variables. We conclude the paper with theoretical implications, practical significance and limitation.

\section{Theoretical Basis and Research Hypothesis}

\subsection{Relationship between Customer Interaction and New Service Development Performance}

The impact of customer interaction on new service development has been highlighted with recent focus on the external environment in the process of new service development. For example, Wang et al. [12] decomposed the interaction between enterprise and customer into two dimensions: process and structure, and proposed that the process factor had a positive impact on the service innovation performance of knowledge in- 
tensive business service firms. Zhang [13] divided new service development performance into process performance and result performance. He obtained that customer participation had a positive effect on new service development process performance through empirical model, and had an indirect effect on result performance through process performance. Carbonell et al. [14] proposed that customer participation could improve the quality and efficiency of new service development, and thus contributed to success of new service development activities. The investigation into 290 knowledge intensive business service firms in the Yangtze River Delta launched by Fan et al. [15] also confirmed this. Therefore, we propose the following hypothesis:

$\mathrm{H} 1$ : Customer interaction has a positive impact on new service development performance.

\subsection{Relationship between Social Capital and New Service Development Performance}

New service development requires a lot of complex knowledge, resources and capabilities, and many important innovation resources usually exist in their social network, so most companies no longer complete all innovation activities by themselves, but integrate resource or capability from external partners beyond organizational boundaries to improve the ability of innovating products and services [16]. At present, research on the impact of social capital on new service development is rare. The empirical study of Chen et al. [17] pointed out that relationship with partners was an important factor affecting service innovation performance. Zhang et al. [18] believed that in the process of interaction between customer and enterprise, customer knowledge transfer helped to enhance knowledge base, and then promoted service innovation of enterprise. Yang [19] obtained that social capital had a positive effect on service innovation performance through empirical analysis of service enterprise. Therefore, we propose the following hypothesis:

H2: Social capital has a positive impact on new service development performance.

\subsection{Relationship among Social Capital, Customer Interaction and New Service Development Performance}

Domestic scholars believe that customer interaction affects new service development performance through specific mediation process. Chen [20] explored the impact of customer participation on service innovation performance from the mediation role of business partner participation. Wang et al. [12] confirmed that knowledge integration had a certain degree of mediating effect on the relationship between enterprise and customer interaction on service innovation performance. From review of above literature, we could find that research on impact of customer interaction on new service development performance from the perspective of regulation effect is relatively lacking.

Although there is not much research in this area, we can still explore possible relationship between them in theory and logic. Lu et al. [21] believed that customer participated in network to promote accumulation of social capital, and network members obtained benefits through social capital, including prior access to knowledge and in- 
formation, new business. New service development of knowledge intensive enterprises required continuous communication and interaction with customers, and was affected by the complex economic and social environment. Efficient and frequent communication with external information nodes can provide information resources flow channels for enterprises in the interactive social network connection [22]. Therefore, we propose the following hypothesis:

H3: Social capital plays a regulatory role in the relationship between customer interaction and new service development performance.

In summary, the research framework constructed in this study is shown in Figure 1. The independent variables are customer interaction and social capital, the dependent variable is new service development performance, and social capital is also the moderating variable of customer interaction to new service development performance.

\section{Research Design and Methods}

\subsection{Sample Selection and Data Collection}

Due to development of China's service industry is not mature, there is no perfect industry system, knowledge intensive business service firms are selected as the research object in empirical study [23]. Based on this, this paper selects knowledge intensive business service firms in the Pearl River Delta as research object. In recent years, knowledge intensive business service firms in the region have developed rapidly and have become engine of economic growth. This study adopts the classification method of domestic scholar Wei et al. [24], to divide knowledge intensive enterprises into four categories: Business services (management consulting, advertising design, legal services), technology services (science and technology exchange, research and development, engineering), information and communication services (transmission services, software, computer services) and financial services (banking, securities, insurance).

The test object of this questionnaire is mainly project director or senior manager, because these people are familiar with new service development project of enterprises, which can maximize ensure the accuracy and effectiveness of this survey. Questionnaires are distributed and recovered mainly through three channels: Firstly, this paper

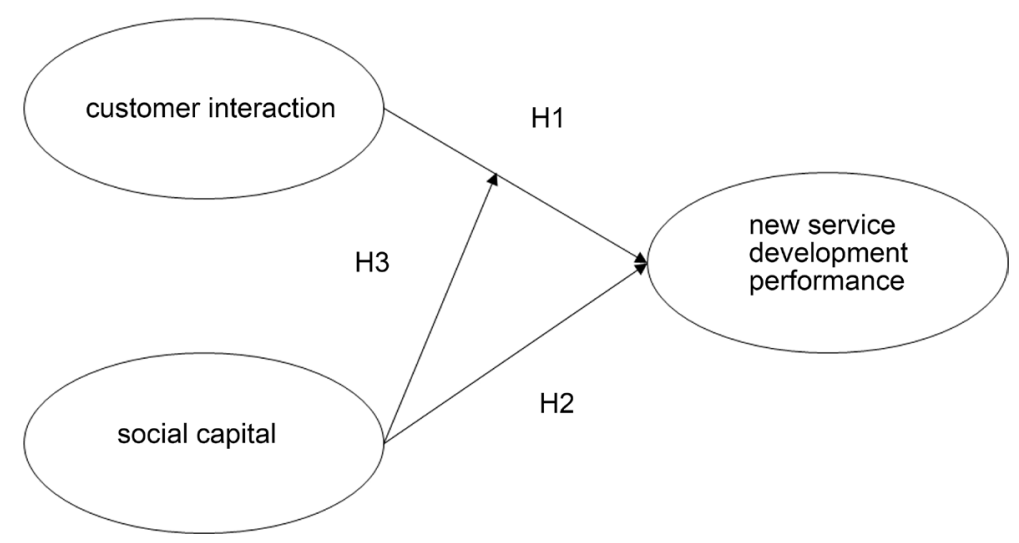

Figure 1. The theoretical model. 
conducts industry screening from school alumni business card and the resources enterprises of mentor, then distributes questionnaires to those who meet the conditions. A total of 750 questionnaires were distributed and 187 valid questionnaires were recovered, so effective recovery rate was $24.93 \%$. Secondly, a total of 7 questionnaires were distributed and recovered through the way of enterprise interview, so effective recovery rate was $100 \%$. Thirdly, a total of 106 questionnaires were distributed through personal connections and 25 valid questionnaires were recovered, so effective recovery rate was $23.58 \%$. Overall, a total of 863 questionnaires were distributed through above three channels and 219 valid questionnaires were recovered from October 2015 to March 2016, so effective recovery rate was $25.38 \%$. In the valid sample, men account for $71.69 \%$ and women are $28.31 \%$; the population between the ages of 46 - 50 account for $39.27 \%$. $89.50 \%$ of the sample population has a university degree or above. The distribution of sample is as follows: financial services $32.42 \%$, information and communication services $24.66 \%$, business services $22.37 \%$ and technology services $20.55 \%$. The sample distribution is relatively average, only financial services are slightly higher. As for sample structure, $14.16 \%$ of them are equipped with less than 100 staffs, $19.63 \%$ with $100-500$ staffs, $15.53 \%$ with 501 - 1000 staffs, $23.74 \%$ with 1001 - 3000 staffs and $26.94 \%$ with over 3000 staffs.

\subsection{Variable Measure}

All variables are measured with five-point Likert scale, from 1 to 5 representing "strongly disagree" to "strongly agree" respectively. Sample items in the scale are shown in Table 1 .

1) Customer interaction. Measurement tools of customer interaction mainly adopted from Wang [25], who integrated case analysis and empirical analysis.

2) Social capital. Scale of corporate social capital mainly referred to study performed by Chen and $\mathrm{Li}$ [26] and Zhang [27].

3) New service development performance. Scale of new service development performance was mainly based on measurement method given by Menor and Roth [28], Liu [29] and Fan et al. [15].

\subsection{Analysis on Reliability and Validity}

1) Reliability analysis

Coefficient Cronbach $\alpha$ was used in the paper to verify the reliability of scale. If Cronbach $\alpha$ is over 0.6 , it means that the factor has good intrinsic consistency to reach requirements. The total Cronbach $\alpha$ of customer interaction, social capital and new service development performance were respectively $0.814,0.849$ and 0.767 , Cronbach $\alpha$ of all variables were greater than 0.6 for sub-scale. It showed that the reliability was consistent with requirements of data measurement.

2) Validity analysis

The scale used in this study was mature ones developed by our predecessors. The content validity of these scales were proved by many empirical studies, which met 
Table 1. Sample items in the scales.

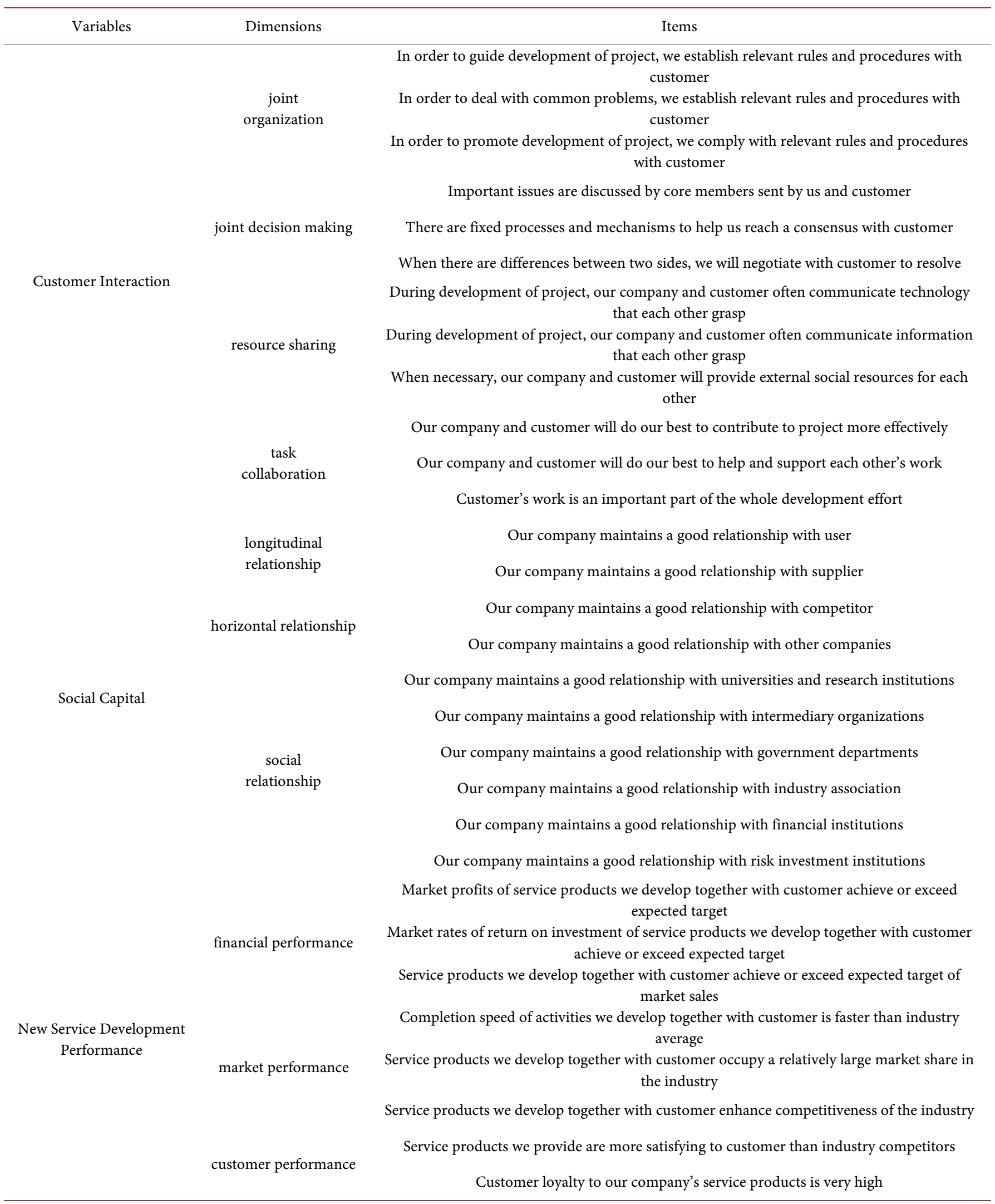


qualified requirements.

Exploratory factor analysis was applied to measure construction validity. KMO values of customer interaction, social capital and new service development performance were $0.703,0.741$ and 0.776 , all greater than 0.7 acceptance criteria. The significance probability in Bartlett sphericity test was $0.000{ }^{(* *)}$, which meant that the sample data could be conducted further factor analysis.

Then we performed principal component analysis to each variable, factor rotation was carried out with maximum variance method. Finally, the factor whose eigenvalue was greater than 1 was extracted. The results of classification and hypothesis classification of this study matched, the scale had good construction validity. Customer interaction extracted four factors, cumulative explained variance is $76.73 \%$. Social capital accordingly extracted three factors, cumulative explained variance is $62.02 \%$. New service development performance extracted three factors, cumulative explained variance is $66.18 \%$.

\section{Result Analysis}

\subsection{Correlation Analysis}

Before structural equation model test, we analyzed correlation between the variables. As shown in Table 2, except for individual variables close to standard value 0.5, other variables are significantly correlated on the basis of no collinearity.

\subsection{Overall Model Test Analysis}

According to Hou et al. [30], this study used method of variables multiplication to measure moderating variable, and introduced interaction term to judge and test the regulation effect. In specific operation, we used product index method from $\mathrm{Li}$ and $\mathrm{Qu}$ [31] to analyze the regulatory role of social capital.

Table 2. The matrix of the correlation coefficient $(\mathrm{N}=219)$.

\begin{tabular}{|c|c|c|c|c|c|c|c|c|c|c|}
\hline & 1 & 2 & 3 & 4 & 5 & 6 & 7 & 8 & 9 & 10 \\
\hline \multicolumn{11}{|l|}{ 1. joint organization } \\
\hline 2. joint decision making & $0.390^{* *}$ & & & & & & & & & \\
\hline 4. task collaboration & $0.310^{\star *}$ & $0.274^{\star *}$ & $0.492^{* \star}$ & & & & & & & \\
\hline 5. longitudinal relationship & $0.033^{* *}$ & $0.132^{\star *}$ & $0.309^{* * *}$ & $0.371^{* *}$ & & & & & & \\
\hline 7. social relationship & $0.271^{\star *}$ & $0.232^{* *}$ & $0.318^{* *}$ & $0.299^{* *}$ & $0.182^{*}$ & $0.444^{\star *}$ & & & & \\
\hline 8. financial performance & $0.131^{\star *}$ & $0.144^{\star}$ & $0.222^{\star *}$ & $0.199^{* *}$ & $0.178^{*}$ & $0.303^{\star *}$ & $0.272^{\star *}$ & & & \\
\hline 9. market performance & $0.256^{* *}$ & $0.220^{*}$ & $0.278^{* *}$ & $0.378^{\star *}$ & $0.319^{* *}$ & $0.379^{\star *}$ & $0.258^{*}$ & $0.346^{*}$ & & \\
\hline 10. customer performance & $0.203^{\star *}$ & $0.314^{\star *}$ & $0.237^{\star * *}$ & $0.376^{* * *}$ & $0.298^{* * *}$ & $0.401^{\star *}$ & $0.369^{* *}$ & $0.387^{\star *}$ & $0.332^{* *}$ & \\
\hline
\end{tabular}

Note: ${ }^{* * *}$ means $\mathrm{p} \leq 0.001{ }^{* *}$ means $\mathrm{p} \leq 0.01,{ }^{\star}$ means $\mathrm{p} \leq 0.05$. 
The overall model of this research was shown in Figure 2. C1, C2 and C3 represented centralized values of average of customer interaction; S1, S2 and S3 represented centralized values of average of social capital; C1S1, C2S2 and C3S3 represented product terms. N1, N2 and N3 represented centralized values of average of three indexes of new service development performance, SS1 represented residual terms of performance. Latent variable was represented in ellipse, and observational variable was in rectangle.

1) Overall model goodness of fit

Result shown in Table 3 showed that all indexes of the model met the criteria. It meant that the model had no need to make other amendments, which could directly test hypothesis.

2) Hypothesis test

From data analysis results in Table 4, it could be seen that standardized value of
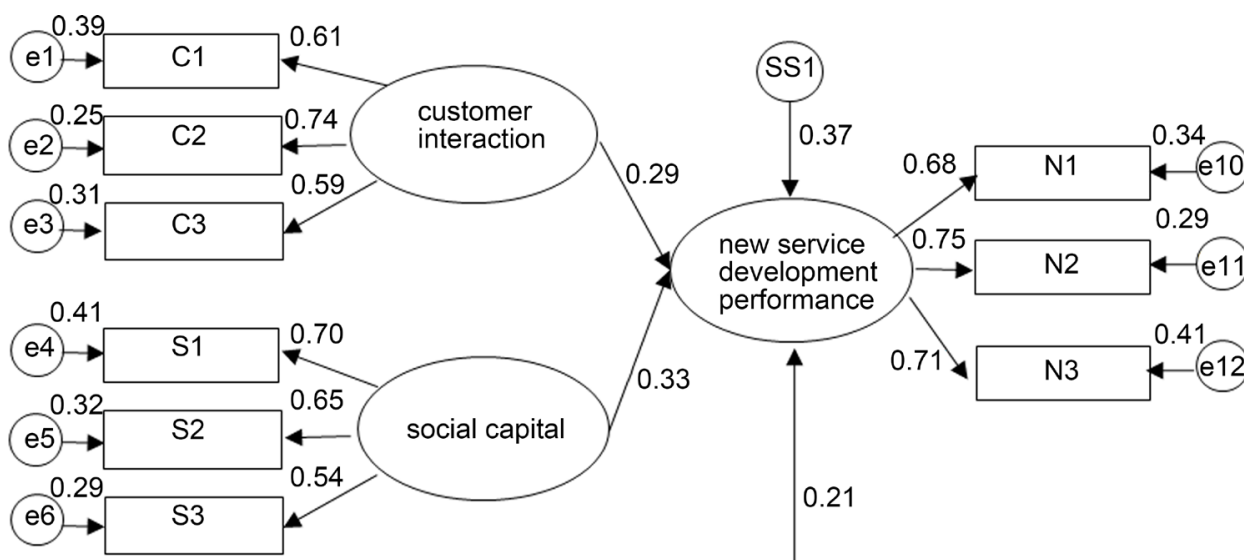

performance
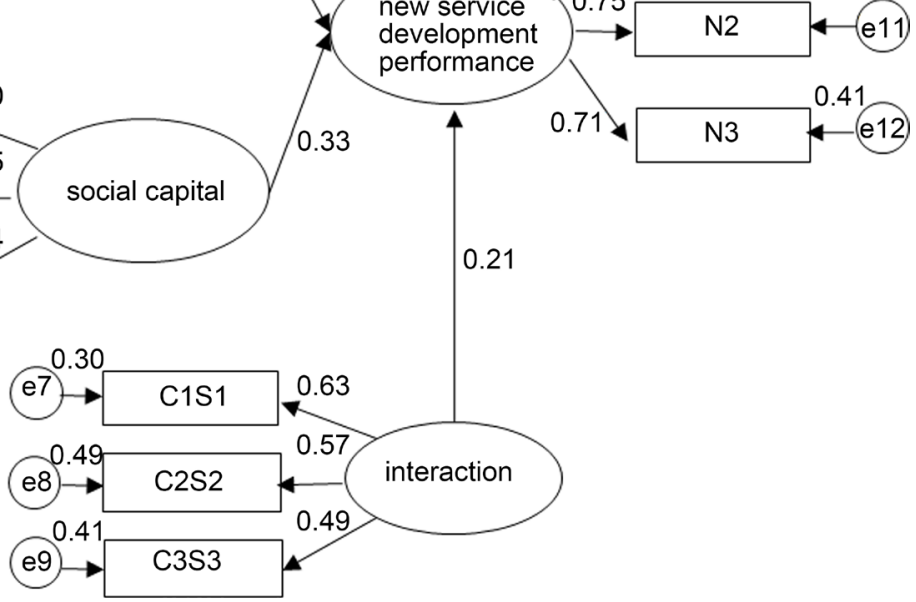

0.21

Figure 2. Overall structure model.

Table 3. Fit index of theoretical model.

\begin{tabular}{cc}
\hline Fit index & Actual value \\
\hline Chi-Square Value/Degrees of Freedom & 1.435 \\
Root Mean Square Residual & 0.039 \\
Root Mean Square Error of Approximation & 0.048 \\
Comparative Fit Index & 0.907 \\
Incremental Fit Index & 0.913 \\
Tucker-Lewis Index & 0.916 \\
Goodness of Fit Index & 0.891 \\
Normed Fit Index & 0.843
\end{tabular}


Table 4. Path coefficient of variable.

\begin{tabular}{|c|c|c|c|c|c|}
\hline Path & $\begin{array}{l}\text { Estimated } \\
\text { value }\end{array}$ & $\begin{array}{l}\text { Actual } \\
\text { value }\end{array}$ & S.E. & C.R. & $\mathrm{p}$ \\
\hline $\begin{array}{c}\text { new service development performance }<--- \\
\text { customer interaction }\end{array}$ & 0.315 & 0.287 & 0.156 & 2.407 & 0.007 \\
\hline $\begin{array}{c}\text { new service development performance }<--- \\
\text { social capital }\end{array}$ & 0.407 & 0.326 & 0.079 & 4.497 & 0.025 \\
\hline $\begin{array}{c}\text { new service development performance }<--- \\
\text { interaction effect }\end{array}$ & 0.401 & 0.205 & 0.524 & 1.121 & 0.036 \\
\hline
\end{tabular}

customer interaction and new service development performance was 0.287 , and reached level of significance $(\mathrm{p}<0.01)$. It indicated that customer interaction positively affected new service development performance. Therefore, $\mathrm{H} 1$ was supported.

Path coefficient of social capital and new service development performance was 0.326 , and reached level of significance $(\mathrm{p}<0.05)$. It indicated that social capital positively affected new service development performance. Therefore, H2 was supported. Path coefficient of interaction effect and new service development performance was 0.205 , and reached level of significance $(p<0.05)$. It indicated that interaction effect of customer interaction and social capital had direct positive influence on new service development performance. Therefore, H3 was supported.

\section{Discussion and Conclusion}

\subsection{Discussion}

1) Customer interaction is an important antecedent variable that influences new service development performance.

We found that customer interaction had a significant positive impact on new service development performance through SEM analysis, especially for joint decision making and resource sharing. The effect of joint decision making on new service development performance took significance testing, which was similar to the conclusion of Tuli et al. [32]. Thus, we should constantly improve negotiation mechanism between enterprises and customers, and promote integration of knowledge, information and ideas on the basis of mutual trust, so as to improve level of new service development. At the same time, this study verified the positive correlation between resource sharing and new service development performance, which was similar to the conclusion of Michel et al. [33]. Therefore, enterprises and customers should continue to improve resource sharing platform and channels, thereby enhancing level of new service development.

2) Social capital is an important antecedent variable that influences new service development performance.

Innovation of this study lay in breaking through traditional enterprises' focus on physical product innovation performance, and turning to new service development performance. Specifically, three dimensions of social capital all had positive effects on improvement of new service development performance. Longitudinal relationship of social capital, including upstream suppliers, downstream customers and end consumers, provided strategic guidance for enterprises to improve supply chain and operation 
in industrial cluster, and found out the possibility of innovation. Horizontal relationship of social capital, including peer competitors and other related enterprises, could provide important market information. Social relationship capital, including government, intermediary, financial and investment institutions, provided professional technology, personnel and financial support for operation of enterprise [34]. Among them, the leading and key users played a big role as a source of innovative ideas, especially user-initiated product innovation provided a lot of valuable information to enterprise [35].

3) Important regulatory role of social capital in the relationship between customer interaction and new service development performance.

Customer interaction affecting new service development performance through specific mediation variable has been proved in many studies [3] [4] [20]. However, to clarify the intrinsic mechanism from the perspective of regulation effect is very limited. In this paper, the existing research model has been developed.

From perspective of longitudinal relationship capital of social capital, if knowledge intensive enterprise can maintain good social relations with user in new service development projects, it is beneficial to discover product and service development opportunity from changing needs of users, as well as improve level of new service development. On the other hand, basing on changing needs of users in the process of customer interaction, enterprise is easier to communicate with suppliers. Enterprise can obtain optimal information quantity and demand price, thus promote their new service development performance.

Because horizontal relationship capital can provide the required information for enterprise, it is at higher level than longitudinal relationship, which is similar to the view of Łopaciuk-Gonczaryk [35] and Yli-Renko et al. [36]. When knowledge intensive enterprise completed project with customer, absorption of information technology from external competitors and other enterprises and mutual integration of resources could better meet needs of customers [37], and thus promoted new service development performance. Social relationship capital of enterprise mainly refers to external organizations such as government, universities, scientific research institutions and financial institutions. As sources of knowledge spillover, these institutions provide enterprises with a lot of effective knowledge and information, which can enhance performance of innovation.

\subsection{Limitation}

Although results of this research have some reference value to theory and practice of new service development, they still exist some deficiencies: First, there may be other moderating variables between customer interaction and new service development performance. Previous empirical study has shown that higher the customer co-production level is, stronger the positive relationship between customer participation and perceived service [38]. Therefore, future research can further consider the role of customer coproduction in the relationship between customer interaction and new service develop- 
ment performance. Second, the research is only aimed at some knowledge intensive business service firms in the Pearl River Delta, the promotion of conclusions needs to be strengthened. The universality of the study remains to be further validated in other areas. Finally, measurement of new service development performance is not limited to three dimensions used in this paper. Domestic and foreign scholars have different views on measurement of performance, so far failed to reach a consensus. For example, Li et al. [39] pointed out that new service development performance is a multidimensional construct. Different dimensions may have different effects.

This study established a structural equation model including moderating variable through collection and collation of literature at home and abroad, and put forward research hypotheses between the three variables. We discussed the relationship between social capital and new service development performance, as well as customer interaction and new service development performance, the regulation effect of social capital on customer interaction and new service development performance was also studied. This paper dug out more meaningful theoretical values of three variables through analysis of 219 valid sample data. In addition, it could provide practical guidance to promote new service development performance and competitive advantage of China's service industry.

\section{References}

[1] Wang, L., Zheng, C.J. and Peng, X.M. (2012) Review and Prospect of Research on Foreign Enterprise and Customer Cooperation Innovation. Foreign Economy and Management, 34, 66-72.

[2] Zhang J. (2014) Effect of Customer Participation on Knowledge Intensive Business Service Firms Innovation Performance. Ph.D. Thesis, Jiangsu University, Zhenjiang.

[3] Ye, P. (2014) Influence of Leading Customer Online Participation on New Service Development Performance of KIBS Enterprises. M.S. Thesis, Zhejiang Gongshang University, Hangzhou.

[4] Leber, M., Weber, C., Adam, F. and Leber, M. (2014) Mobile Application as an Innovative Supply Chain Concept and the Impact of Social Capital. International Journal of Simulation Modelling, 13, 135-146. https://doi.org/10.2507/IJSIMM13(2)1.255

[5] Han, W., Yang, J. and Bao, F.N. (2013) Initial Resources, Social Capital and Efficiency of Entrepreneurial Action: A Research Based on Resource Matching. Nankai Management Review, 16,149-160.

[6] Feng, T.W. and Sun, L.Y. (2013) Effect of External Participation on Firm Performance in the Process of New Product Development. Management Science, 26, 28-39.

[7] Martínez-Cañas, R., Sáez-Martínez, F.J. and Ruiz-Palomino, P. (2012) Knowledge Acquisition's Mediation of Social Capital-Firm Innovation. Journal of Knowledge Management, 16, 61-76. https://doi.org/10.1108/13673271211198945

[8] Dai, Y. and Zhu, G.L. (2011) Research on Social Capital and Innovation Performance with Absorptive Capacity as Moderator-An Empirical Analysis Based on Guangdong Enterprises. China Soft Science, 1, 80-84.

[9] Kindström, D., Kowalkowski, C. and Sandberg, E. (2013) Enabling Service Innovation: A Dynamic Capabilities Approach. Journal of Business Research, 66, 1063-1073.

https://doi.org/10.1016/j.jbusres.2012.03.003 
[10] Gallouj, F. and Weinstein, O. (1997) Innovation in Services. Research Policy, 26, 537-556. https://doi.org/10.1016/S0048-7333(97)00030-9

[11] Von Hippel, E. (1986). Lead Users: A Source of Novel Product Concepts. Management Science, 32, 791-805. https://doi.org/10.1287/mnsc.32.7.791

[12] Wang, L., Wei, J. and Zhou, D. (2015) Research on the Effect Mechanism of Interaction between Enterprise and Customer on KIBS Enterprise Service Innovation Performance. Research and Development Management, 27, 126-136.

[13] Zhang, Y.Z. (2011). Empirical Study on Environmental Change, Customer Participation and New Service Development Performance. MS Thesis, Lanzhou University, Lanzhou.

[14] Carbonell, P., Rodríguez-Escudero, A.I. and Pujari, D. (2009) Customer Involvement in New Service Development: An Examination of Antecedents and Outcomes. Journal of Product Innovation Management, 26, 536-550. https://doi.org/10.1111/j.1540-5885.2009.00679.x

[15] Fan, J., Qiu, Y. and Deng, F.T. (2013) Research on the Impact of Customer Participation on New Service Development Performance in KIBS Industry. Technology Advancement and Countermeasures, 30, 71-78.

[16] Heimeriks, K.H. and Duysters, G. (2007) Alliance Capability as a Mediator between Experience and Alliance Performance: An Empirical Investigation into the Alliance Capability Development Process. Journal of Management Studies, 44, 25-49. https://doi.org/10.1111/j.1467-6486.2006.00639.x

[17] Chen, Y.H., Xue, R.T. and Huang, Z.X. (2009) Research on the Relationship between Network Mosaic and Service Innovation Performance-A Case Study of Taiwan B2B Software Service Provider. Journal of Information Management (Taiwan), 16, 75-96.

[18] Zhang, R.Y., Liu, X.M., Wang, H.Z. and Nie, K. (2010) Effects of Customer-Enterprise Interaction on Service Innovation: A Perspective from Organizational Learning. Chinese Journal of Management, 7, 218-224.

[19] Yang, J.H. (2013) Correlation Study of Corporate Social Capital, Market Orientation, Organizational Learning and Service Innovation Performance. M.S. Thesis, South China University of Technology, Guangzhou.

[20] Chen, J.H. (2013) The Impact of Customer and Business Partner Involvement on Service Innovation Performance. MS Thesis, South China University of Technology, Guangzhou.

[21] Lu, J.Y., Wang, Y.G. and Huang, Y.C. (2009) A Study on the Relationship between Customer Involvement in Service Innovation and Customer Knowledge Transfer: A Theoretical Review and Model Construction Based on Social Capital Perspective. Finance and Trade Economics, No. 12, 128-133.

[22] Dyer, J.H. and Singh, H. (1998) The Relational View: Cooperative Strategy and Sources of Interorganizational Competitive Advantage. Academy of Management Review, 23, 660-679.

[23] Strambach, S. (2002) Change in the Innovation Process: New Knowledge Production and Competitive Cities-The Case of Stuttgart. European Planning Studies, 10, 215-231. https://doi.org/10.1080/09654310120114508

[24] Wei, J., Tao, Y. and Wang, L. (2007) Research on the Concept and Classification of Knowledge Intensive Business Service Firms. China Soft Science, No. 1, 33-41.

[25] Wang, L. (2012) A Study on Mechanism of Enterprise-Customer Interaction to Service Innovation Performance. $\mathrm{PhD}$ Thesis, Zhejiang University, Hangzhou.

[26] Chen, J. and Li, F.Y. (2001) Social Capital: A Sociological Interpretation of Technological Innovation. Research in Science, 19, 102-107.

[27] Zhang, F.H. (2004) Social Capital and Technological Innovation Performance of Know- 
ledge-Based Enterprises. PhD Thesis, Zhejiang University, Hangzhou.

[28] Menor, L.J. and Roth, A.V. (2007) New Service Development Competence in Retail Banking: Construct Development and Measurement Validation. Journal of Operations Management, 25, 825-846. https://doi.org/10.1016/j.jom.2006.07.004

[29] Liu, S.Z. (2009) Research on the Effect Mechanism of Organizational Learning Capability on New Service Development Performance. Research in Science, 27, 411-417.

[30] Hou, J.T., Wen, Z.L. and Chen, Z.J. (2004) Structural Equation Model and Its Applications. Vol. 7, Education Science Press, Beijing, 14-15.

[31] Li, J.M. and Qu, C.Y. (2007) Latent Variable Interaction Analysis Model and Its Implementation on SAS. Understanding and Practice of Mathematics, 37, 31-37.

[32] Tuli, K.R., Kohli, A.K. and Bharadwaj, S.G. (2007) Rethinking Customer Solutions: From Product Bundles to Relational Processes. Journal of Marketing, 71, 1-17.

https://doi.org/10.1509/jmkg.71.3.1

[33] Michel, S., Brown, S.W. and Gallan, A.S. (2008) Service-Logic Innovations: How to Innovate Customers, Not Products. California Management Review, 50, 49-65. https://doi.org/10.2307/41166445

[34] Jian, Z. and Zhou, Y. (2015) Corporate Social Capital, Market Orientation, Organizational Learning and Service Innovation Performance: An Empirical Survey in the Pearl River Delta of China. Journal of Industrial Engineering and Management, 8, 303-321. https://doi.org/10.3926/jiem.1318

[35] Łopaciuk-Gonczaryk, B. (2011) Corporate Social Capital: Results of Empirical Research in a Financial Institution. Procedia-Social and Behavioral Sciences, 10, 62-67. https://doi.org/10.1016/j.sbspro.2011.01.009

[36] Yli-Renko, H., Autio, E. and Tontti, V. (2002) Social Capital, Knowledge, and the International Growth of Technology-Based New Firms. International Business Review, 11, 279304. https://doi.org/10.1016/S0969-5931(01)00061-0

[37] Zhou, X.H. and Chen, C.M. (2004) Enterprise Social Capital and Sustainable Competitive Advantage. China Industrial Economy, No. 5, 90-96.

[38] Cheung, M.F. and To, W.M. (2011) Customer Involvement and Perceptions: The Moderating Role of Customer Co-Production. Journal of Retailing and Consumer Services, 18, 271-277. https://doi.org/10.1016/j.jretconser.2010.12.011

[39] Li, L., Zhao, X.D. and Yang, H.Z. (2012) Review and Trend Outlook of New Service Development Abroad. Foreign Economy and Management, 34, 36-45. 
Submit or recommend next manuscript to SCIRP and we will provide best service for you:

Accepting pre-submission inquiries through Email, Facebook, LinkedIn, Twitter, etc. A wide selection of journals (inclusive of 9 subjects, more than 200 journals)

Providing 24-hour high-quality service

User-friendly online submission system

Fair and swift peer-review system

Efficient typesetting and proofreading procedure

Display of the result of downloads and visits, as well as the number of cited articles

Maximum dissemination of your research work

Submit your manuscript at: http://papersubmission.scirp.org/

Or contact ajibm@scirp.org 